University of Nebraska - Lincoln

DigitalCommons@University of Nebraska - Lincoln

\title{
Soil Microbes Compete Strongly with Plants for Soil Inorganic and Amino Acid Nitrogen in a Semiarid Grassland Exposed to Elevated CO2 and Warming
}

\author{
Janet Chen \\ University of Wyoming \\ Yolima Carrillo \\ University of Western Sydney \\ Elise Pendall \\ University of Western Sydney, pendall@uwyo.edu \\ Feike A. Dijkstra \\ University of Sydney, feike.dijkstra@sydney.edu.au \\ R. Dave Evans \\ USDA-ARS
}

See next page for additional authors

Follow this and additional works at: https://digitalcommons.unl.edu/usdaarsfacpub

Chen, Janet; Carrillo, Yolima; Pendall, Elise; Dijkstra, Feike A.; Evans, R. Dave; Morgan, Jack A.; and Williams, David G., "Soil Microbes Compete Strongly with Plants for Soil Inorganic and Amino Acid Nitrogen in a Semiarid Grassland Exposed to Elevated CO2 and Warming" (2015). Publications from USDA-ARS / UNL Faculty. 1605.

https://digitalcommons.unl.edu/usdaarsfacpub/1605

This Article is brought to you for free and open access by the U.S. Department of Agriculture: Agricultural Research Service, Lincoln, Nebraska at DigitalCommons@University of Nebraska - Lincoln. It has been accepted for inclusion in Publications from USDA-ARS / UNL Faculty by an authorized administrator of DigitalCommons@University of Nebraska - Lincoln. 


\section{Authors}

Janet Chen, Yolima Carrillo, Elise Pendall, Feike A. Dijkstra, R. Dave Evans, Jack A. Morgan, and David G. Williams 


\title{
Soil Microbes Compete Strongly with Plants for Soil Inorganic and Amino Acid Nitrogen in a Semiarid Grassland Exposed to Elevated $\mathrm{CO}_{2}$ and Warming
}

\author{
Janet Chen, ${ }^{1 *}$ Yolima Carrillo, ${ }^{2}$ Elise Pendall, ${ }^{2,3}$ Feike A. Dijkstra, ${ }^{4}$ \\ R. Dave Evans,${ }^{5}$ Jack A. Morgan, ${ }^{6}$ and David G. Williams ${ }^{3}$
}

\begin{abstract}
${ }^{1}$ Department of Ecosystem Science and Management \& Program in Ecology, University of Wyoming, Laramie, Wyoming 82071, USA; ${ }^{2}$ Hawkesbury Institute for the Environment, University of Western Sydney, Penrith, New South Wales 2751, Australia; ${ }^{3}$ Department of Botany and Program in Ecology, University of Wyoming, Laramie, Wyoming 82071, USA; ${ }^{4}$ Department of Environmental Sciences, Centre for Carbon, Water and Food, The University of Sydney, Camden, New South Wales 2570, Australia; ${ }^{5}$ Rangeland Resources Research Unit, USDA Agricultural Research Service, Fort Collins, Colorado 80526, USA; ${ }^{6}$ School of Biological Sciences, WSU Stable Isotope Core Facility, Washington State University, Pullman, Washington 99163, USA
\end{abstract}

\begin{abstract}
Free amino acids (FAAs) in soil are an important $\mathrm{N}$ source for plants, and abundances are predicted to shift under altered atmospheric conditions such as elevated $\mathrm{CO}_{2}$. Composition, plant uptake capacity, and plant and microbial use of FAAs relative to inorganic $\mathrm{N}$ forms were investigated in a temperate semiarid grassland exposed to experimental warming and free-air $\mathrm{CO}_{2}$ enrichment. FAA uptake by two dominant grassland plants, Bouteloua gracilis and Artemesia frigida, was determined in hydroponic culture. B. gracilis and microbial N preferences were then investigated in experimental field plots using isotopically labeled FAA and inorganic $\mathrm{N}$ sources. Alanine and phenylalanine concentra-
\end{abstract}

tions were the highest in the field, and $B$. gracilis and $A$. frigida rapidly consumed these FAAs in hydroponic experiments. However, B. gracilis assimilated little isotopically labeled alanine, ammonium and nitrate in the field. Rather, soil microbes immobilized the majority of all three $\mathrm{N}$ forms. Elevated $\mathrm{CO}_{2}$ and warming did not affect plant or microbial uptake. FAAs are not direct sources of $\mathrm{N}$ for $B$. gracilis, and soil microbes outcompete this grass for organic and inorganic $\mathrm{N}$ when $\mathrm{N}$ is at peak demand within temperate semiarid grasslands.

Key words: amino acids; global change; grasslands; nitrogen uptake; ${ }^{13} \mathrm{C} ;{ }^{15} \mathrm{~N}$.
Received 7 October 2014; accepted 15 February 2015; published online 2 April 2015

Author contributions JC conceived of the study and analyzed the data. JC, YC, and FAD performed research. JC, YC, JAM, RDE, and DGW contributed to the design of the study. All authors contributed to writing the article.

*Corresponding author; e-mail: janet.chen@unh.edu

\section{INTRODUCTION}

Nitrogen $(\mathrm{N})$ availability will determine terrestrial responses to global change because of its role as a limiting nutrient for plant growth and productivity (West 1991). Understanding future changes in soil $\mathrm{N}$ forms and plant use with increases in atmospheric $\mathrm{CO}_{2}$ concentration and warmer 
temperatures is important for predicting the extent of plant response to global change. Plants assimilate soil inorganic $\mathrm{N}\left(\mathrm{NH}_{4}{ }^{+}\right.$and $\left.\mathrm{NO}_{3}{ }^{-}\right)$and organic $\mathrm{N}$, such as free amino acids (FAAs). The latter can be in comparatively high concentrations in soil solution, even relative to peptides, and likely constitute the majority of dissolved organic N (Warren 2013). Plants compete with microbes for N (Jackson and others 1989; Schimel and Chapin 1996; Lipson and Monson 1998), and plant $\mathrm{N}$ uptake is often facilitated by mycorrhizae (Lipson and others 1999; Hodge and others 2000; Andresen and others 2008). However, plant $\mathrm{N}$ uptake can also occur independent of mycorrhizae using mechanisms such as root epidermal $\mathrm{N}$ transporters (Williams and Miller 2001; Lee and others 2007). Although plants can directly take up soil FAAs, we know relatively little about the role of FAAs compared to inorganic $\mathrm{N}$ as a plant $\mathrm{N}$ source within most terrestrial ecosystems.

Several experiments have investigated global change effects on FAAs and their uptake by plants and observed variable effects of elevated $\mathrm{CO}_{2}$ and warming (Hofmockel and others 2007; Andresen and others 2009; Jin and Evans 2010). However, further investigation in a variety of ecosystems is necessary to clarify the role of FAAs as a plant $\mathrm{N}$ source as well as determine the effects of elevated $\mathrm{CO}_{2}$ and warming. The progressive $\mathrm{N}$ limitation hypothesis (Luo and others 2004) proposes that elevated atmospheric $\mathrm{CO}_{2}$ will increase $\mathrm{N}$ sequestration in biomass over time and increasingly limit productivity response to increasing $\mathrm{CO}_{2}$. Although observations from forests do not support this hypothesis (Zak and others 2003), evidence of progressive $\mathrm{N}$ limitation with elevated $\mathrm{CO}_{2}$ has been found in other ecosystem types (Luo and others 2006) including a grassland (Newton and others 2010), and should therefore be explored further. As $\mathrm{N}$ becomes more limiting under elevated $\mathrm{CO}_{2}$, plants may increasingly compete with soil microbes for FAAs as a source of $\mathrm{N}$ and bypass $\mathrm{N}$ mineralization as a rate-limiting step of plant $\mathrm{N}$ availability (Schimel and Bennett 2004). Studies in cold temperate forests have demonstrated that hardwood and conifer trees increase FAA uptake as N limitation increases and FAA pools become comparable to inorganic N (Finzi and Berthrong 2005; GalletBudynek and others 2009). However, climate warming that will accompany increases in atmospheric $\mathrm{CO}_{2}$ may stimulate $\mathrm{N}$ mineralization and $\mathrm{N}$ availability (Pendall and others 2004; Dijkstra and others 2010), potentially reducing plant depen- dence on FAAs as a N source (Schimel and Bennett 2004).

Assessing $\mathrm{N}$ use in grasslands is especially important because this biome accounts for $9 \%$ of global terrestrial net primary production (Saugier and others 2001). Plant biomass production in temperate ecosystems, such as temperate grasslands, is often limited by $\mathrm{N}$ and water (Vitousek and Howarth 1991; King and others 2004), and N limitation likely will be exacerbated under elevated atmospheric $\mathrm{CO}_{2}$ (Luo and others 2004). Although $\mathrm{N}$ limitation in grasslands may not be as severe as that in Arctic tundra and alpine ecosystems with slow turnover of soil organic matter (Chapin and others 1993), $\mathrm{N}$ mineralization rates in temperate grassland soils are low (Kaye and others 2002), thus potentially making organic $\mathrm{N}$, such as FAAs, an important $\mathrm{N}$ source. FAAs are abundant in a number of grassland ecosystems (Amelung and others 2006), and roots of a number of grassland plant species are capable of taking up FAAs (Harrison and others 2007, 2008). Yet no study has investigated FAA composition, the capacity of native plants to take up FAAs and plant preference for FAAs to inorganic $\mathrm{N}$ all within a single grassland ecosystem.

The composition of FAAs varies across spatial and temporal scales (Raab and others 1999; WerdinPfisterer and others 2009). This variation is presumably driven by the influence of soil moisture content, $\mathrm{pH}$, and temperature on rates of FAA production and consumption (Falkengren-Grerup and others 2000; Brzostek and others 2012). FAAs are primarily released into the soil by depolymerization of organic matter and consumed by plants and microbes to meet $\mathrm{N}$ and $\mathrm{C}$ demands (Schimel and Bennett 2004). Pulses of microbial and soilprotected amino acids are also released into the soil after freeze-thaw events and associated breakdown of microbial cells and soil aggregates (Lipson and Monson 1998; Larsen and others 2002).

Uptake capacity experiments can identify the potential for different plant species to take up FAAs. To clearly determine if plant roots can take up FAAs, it is necessary to eliminate external environmental factors that can inhibit root uptake, such as microbial and interplant competition. Hydroponic culture experiments with controlled environments are one way to achieve such conditions. Experiments in hydroponic culture demonstrate that plant uptake capacity of FAAs varies with the available forms of amino acid, regulation of $\mathrm{N}$ transport proteins, root-to-shoot ratios, and 
plant species (Chapin and others 1993; Raab and others 1996; Falkengren-Grerup and others 2000; Lee and others 2007). Although characterizing FAA composition and plant uptake capacity can determine the potential role of FAAs as an $\mathrm{N}$ source, field studies on plant uptake are ultimately required to determine the importance of FAAs as a direct $\mathrm{N}$ source.

To our knowledge, no study has investigated the effect of elevated atmospheric $\mathrm{CO}_{2}$ and warming on FAA composition together with plant $\mathrm{N}$ preference. We investigated the effects of elevated $\mathrm{CO}_{2}$ and warming on FAAs and plant $\mathrm{N}$ use in a temperate semiarid grassland by measuring FAA pools, plant uptake capacity, and preferential $\mathrm{N}$ uptake in both hydroponic culture and field studies. We predicted plants would increase consumption of FAAs and compete with soil microbes for the organic $\mathrm{N}$ source relative to inorganic $\mathrm{N}$ under elevated $\mathrm{CO}_{2}$ because of increased $\mathrm{N}$ limitation. Further, combined elevated atmospheric $\mathrm{CO}_{2}$ and warming should lead to plant $\mathrm{N}$ use similar to that in ambient conditions because of the stimulation of $\mathrm{N}$ mineralization by warming.

\section{Materials And Methods}

\section{Study Site}

We assessed FAA composition and uptake at the prairie heating and $\mathrm{CO}_{2}$ enrichment (PHACE) experiment located at the US Department of Agriculture, Agricultural Research Service (USDAARS), High Plains Grasslands Research Station in southeastern Wyoming, USA $\left(41^{\circ} 11^{\prime} \mathrm{N}, 104^{\circ} 54^{\prime} \mathrm{W}\right)$. The ecosystem is a northern mixed-grass prairie dominated by a C4 grass, Bouteloua gracilis (H.B.K.) Lag., and two C3 grasses, Hesperostipa comata Trin and Rupr. and Pascopyrum smithii (Rydb.). These three grasses together comprise over $50 \%$ of the total aboveground biomass. Additional plant species include the sub-shrub Artemisia frigida Willd., together with forbs and other grasses. N-fixing legumes are a very minor component in the experimental plots, and plant productivity is still limited by $N$ (Blumenthal 2009). The growing season extends from April through August, with over $70 \%$ of annual (384 mm mean) precipitation occurring during the growing season (1973-2005 HPGRS data). Mean air temperatures are $-2.5^{\circ} \mathrm{C}$ in winter and $17.5^{\circ} \mathrm{C}$ in summer. Soils consist of a fine-loamy, mixed mesic Aridic Argiustoll with a $\mathrm{pH}$ of 7.0. Soil inorganic $\mathrm{N}$ pool sizes during the growing season range from 0.19 to $0.47 \mathrm{~g} \mathrm{~m}^{-2}$ from 5 to $15 \mathrm{~cm}$ (Dijkstra and others 2010).

\section{PHACE Experimental Design}

Twenty 3.4-m-diameter plots were established for manipulation of $\mathrm{CO}_{2}$ and temperature using freeair $\mathrm{CO}_{2}$ enrichment (FACE) technology (Miglietta and others 2001) and infrared heaters (Kimball and others 2008). Tubing around the periphery of FACE plots emitted $\mathrm{CO}_{2}$ to maintain atmospheric $\mathrm{CO}_{2}$ concentrations of $600 \pm 40 \mathrm{ppm}$ during the growing season (initiated April 2006). Ceramic heaters $1.5 \mathrm{~m}$ above each plot $(1000 \mathrm{~W}$; Mor Electric Heating Assoc., Inc, Comstock Park, Michigan, USA) warmed treated plots by $1.5^{\circ} \mathrm{C}$ above ambient temperature during the day and $3^{\circ} \mathrm{C}$ during the night year round (initiated April 2007). Elevated $\mathrm{CO}_{2}$ and warming treatments were implemented in a fully factorial design of ambient $\mathrm{CO}_{2}$ and temperature (ct), elevated $\mathrm{CO}_{2}$ and ambient temperature $(\mathrm{Ct})$, ambient $\mathrm{CO}_{2}$ and elevated temperature $(\mathrm{CT})$, or elevated $\mathrm{CO}_{2}$ and elevated temperature (CT), with five replicate plots per treatment.

Volumetric soil moisture content was measured within experimental plots at 10, 20, 40, 60, and $80 \mathrm{~cm}$ depths using soil moisture probes (EnviroSMART probe; Sentek Sensor Technologies, Stepney, Australia), but only data from $10 \mathrm{~cm}$ are reported. Air and soil temperatures $10 \mathrm{~cm}$ above soil and 3 and $10 \mathrm{~cm}$ below the soil surface were measured using fine-wire thermocouples. Temperature and moisture were measured at hourly time intervals. Temperature and moisture measurements were averaged to obtain daily and monthly mean values.

\section{Determination of FAAs in PHACE Plots}

To identify soil FAAs, two $1.5-\mathrm{cm}$-diameter cores were collected from each PHACE experimental plot in April 2008. Soils from $0-5$ to $5-15 \mathrm{~cm}$ were placed on ice and returned to a laboratory for processing within $24 \mathrm{~h}$. Soils were homogenized, and subsamples were processed and mixed by shaking in either deionized water or $0.05 \mathrm{M} \mathrm{K}_{2} \mathrm{SO}_{4}$ solutions ( $1: 5$ soil to solution ratio), two commonly used FAA and $\mathrm{N}$ extraction solutions, for $60 \mathrm{~min}$. The two different extraction methods were performed to address bias of extractant type (Inselsbacher 2014). Soil slurries were then filtered prior to storage and analysis by ultra performance liquid chromatography (UPLC). Further details on sample preparation and analysis using UPLC can be found in Chen and Williams (2013). Abundance of FAAs in soil extracts was calculated as the molar content of individual FAAs per gram of soil. 


\section{Plant FAA Uptake Capacity Experiment}

Bouteloua gracilis and A. frigida seeds were collected at maturation in the late summer and fall of 2007 near the PHACE experimental site and grown in hydroponic culture to test plant FAA uptake capacity and effects of elevated $\mathrm{CO}_{2}$. Seeds were grown in hydroponic culture in December of 2009 as described by Lee and others (2007). Initial experiments determined that $B$. gracilis and $A$. frigida maintain healthy growth in hydroponic

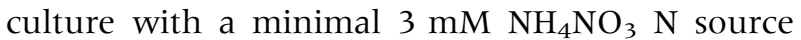
(Chen 2006). Hydroponic culture containers were placed in growth chambers (Environmental Growth Chamber, Chagrin Falls, OH), and plants were grown with $14 \mathrm{~h}$ photoperiods. Day periods consisted of $200 \mu \mathrm{mol} \mathrm{m} \mathrm{m}^{-2} \mathrm{~s}^{-1}$ PPFD at plant canopy height, $20^{\circ} \mathrm{C}$, and $57 \%$ humidity. Higher PPFD caused damage to plants in hydroponic culture, and optimal growth was observed at PPFDs lower than $200 \mu \mathrm{mol} \mathrm{m} \mathrm{m}^{-2} \mathrm{~s}^{-1}$. Night periods consisted of no light and $16^{\circ} \mathrm{C}$ and $74 \%$ humidity. Hydroponic culture containers were equally divided between two chambers that were given pure $\mathrm{CO}_{2}$ to elevate atmospheric $\mathrm{CO}_{2}$ to $600 \mathrm{ppm}$ and two chambers that were kept at present-day ambient $\mathrm{CO}_{2}$ conditions. Hydroponic solution was refilled every 2 days to maintain full root immersion, and solutions were refreshed weekly.

After 36 days of growth, seedlings were prepared for evaluation of inorganic $\mathrm{N}$ and FAA uptake capacity and effects of elevated $\mathrm{CO}_{2}$. Eight $A$. frigida and eight $B$. gracilis seedlings $(N=8$ per growth chamber treatment) were used to investigate uptake of alanine. Four seedlings of each plant species from both ambient and elevated $\mathrm{CO}_{2}$ growth chambers were also used to investigate uptake of phenylalanine and another four were used for nitrate uptake studies $(N=4$ per growth chamber treatment). Seedlings were removed from hydroponic culture boxes, and roots were gently hand rinsed in fresh $\mathrm{N}$-free hydroponic solution to remove any residual $\mathrm{N}$ and microorganisms at the root surface. Cleaned roots of each seedling were then placed in separate $15 \mathrm{ml}$ conical centrifuge tubes wrapped in aluminum foil (to prevent root light exposure) with $13 \mathrm{ml}$ of freshly prepared hydroponic solution containing $3 \mathrm{mM}$ alanine, phenylalanine, or nitrate as a sole $\mathrm{N}$ source (equimolar amounts of $\mathrm{N}$ ). Although $\mathrm{N}$ source concentrations of $3 \mathrm{mM}$ were much higher than other feeding studies (Chapin and others 1993; Raab and others 1996, 1999; Falkengren-Grerup and others 2000), we decided to maintain similar amounts of $\mathrm{N}$ supplied during the growing period to prevent $\mathrm{N}$ starvation responses. Shoot tissue remained above the top of the centrifuge tube with exposure to light in growth chambers. At $0,30,60$, and 180 min after $\mathrm{N}$ feeding, $200 \mu \mathrm{l}$ of solution was harvested from each plant tube, frozen, and prepared for analysis by UPLC (Chen and Williams 2013). After the 180 min feeding period, plant tissue was dried and weighed to determine plant biomass.

After 122 days of growth, an additional set of hydroponic culture seedlings $(N=2$ per growth chamber treatment) was used in an L- $\left[2-{ }^{14} \mathrm{C}\right]$ alanine uptake experiment to determine allocation of alanine $\mathrm{C}$ within plant tissue. Plants were transferred to a fume hood with a $42 \mathrm{~W}$ compact fluorescent light bulb $16 \mathrm{~cm}$ above shoots $4 \mathrm{~h}$ prior to ${ }^{14} \mathrm{C}$ labeling. Roots were then rinsed in $\mathrm{N}$-free hydroponic solution and placed in $50 \mathrm{ml}$ conical centrifuge tubes wrapped in aluminum foil with $48 \mathrm{ml}$ of hydroponic solution containing $3 \mathrm{mM}$ alanine and $0.1 \mu \mathrm{Ci}$ of $\mathrm{L}-\left[2-{ }^{14} \mathrm{C}\right]$ alanine $(\geq 98 \%$ radiochemical purity) as a sole $\mathrm{N}$ source. Plant roots were rinsed in $0.5 \mathrm{mM} \mathrm{CaCl} 2$ solution after 180 min of feeding, blotted dry with Kimwipes, press dried, and then exposed on X-ray film in a $-80^{\circ} \mathrm{C}$ freezer for 8 months prior to developing radiographs of plant alanine $-{ }^{14} \mathrm{C}$ distribution.

\section{FAA Preference and PHACE Field Experiment}

We investigated B. gracilis ability to consume FAAs and inorganic $\mathrm{N}$ in the field over a 2-day period in June of 2010 during peak growth. Four individual $B$. gracilis plants within each PHACE plot were isolated by $20 \mathrm{~cm}$ long, 5 -cm-diameter PVC pipes inserted $15 \mathrm{~cm}$ into the soil. Shortly after isolation by midday, $1.88 \times 10^{-5} \mathrm{~mol} \mathrm{~N}$ (concentrations of $\mathrm{N}$ label required to detect ${ }^{15} \mathrm{~N}$ presence in plant tissue (Andresen and others 2008, 2009)) of alanine, $\mathrm{KNO}_{3}$, and $\mathrm{NH}_{4} \mathrm{Cl}$ each were injected with $20 \mathrm{ml}$ of deionized water approximately $1 \mathrm{~cm}$ below soil surface within all collars. The solution was injected at four equidistant points $(5 \mathrm{ml}$ per point) within the soil collar. The "control" collar received $\mathrm{KNO}_{3}, \mathrm{NH}_{4} \mathrm{Cl}$, and alanine that were not isotopically labeled. In another collar, ${ }^{15} \mathrm{NH}_{4} \mathrm{Cl}\left({ }^{15} \mathrm{~N}, 98 \%\right)$ and non-labeled alanine and $\mathrm{KNO}_{3}$ were introduced into the soil. In the third collar, $\mathrm{K}^{15} \mathrm{NO}_{3}\left({ }^{15} \mathrm{~N}\right.$, $99 \%$ ) and non-labeled alanine and $\mathrm{NH}_{4} \mathrm{Cl}$ were introduced into the soil, and in the fourth collar, dual-labeled L-alanine- $-2{ }^{13} \mathrm{C}-{ }^{15} \mathrm{~N} \quad\left({ }^{13} \mathrm{C}, 99 \% ;{ }^{15} \mathrm{~N}\right.$, $98 \%$ ) and non-labeled $\mathrm{NH}_{4} \mathrm{Cl}$ and $\mathrm{KNO}_{3}$ were provided. 
Collars were removed from soil after a $180 \mathrm{~min}$ feeding to retrieve the intact $B$. gracilis and soil. Soils within collars were visibly moist throughout the entire core. Soils, including aggregates removed from plant roots, were immediately placed on ice for transport to a laboratory for storage at $4^{\circ} \mathrm{C}$. B. gracilis plant roots were rinsed in $0.05 \mathrm{M} \mathrm{CaCl}_{2}$ prior to freezing of whole plant tissue in liquid nitrogen, storage on dry ice and transport back to the laboratory for storage at $-20^{\circ} \mathrm{C}$. Within $48 \mathrm{~h}$, soils were sieved to remove rocks and coarse debris. C and $\mathrm{N}$ from soil subsamples for each collar were extracted with $0.05 \mathrm{M} \mathrm{K}_{2} \mathrm{SO}_{4}$ on a shaker for $1 \mathrm{~h}$, and another soil subsample was vacuum-incubated with chloroform for $24 \mathrm{~h}$ to release microbial $\mathrm{C}$ and $\mathrm{N}$ (Brookes and others 1985) before extraction with $\mathrm{K}_{2} \mathrm{SO}_{4}$ as described above. Extracts were stored at $-20^{\circ} \mathrm{C}$ prior to chemical and stable isotope analysis. Chemical and stable isotope analyses were performed on extracts dried at $65^{\circ} \mathrm{C}$ overnight. Soil subsamples were weighed and placed in $60^{\circ} \mathrm{C}$ for over $48 \mathrm{~h}$ and reweighed to determine soil moisture content within collars after the experimental feeding.

Plant material was freeze-dried, and root, crown (junction between root and shoots), and shoot tissues were weighed and ground separately. Seven milliliters of $\mathrm{K}_{2} \mathrm{SO}_{4}$ extracts were dried at $60^{\circ} \mathrm{C}$ to crystal form, weighed, and then ground into a powder. Ground samples were analyzed for $\mathrm{C}$ and $\mathrm{N}$ content and fractional abundances $(F)$ of ${ }^{13} \mathrm{C}$ and ${ }^{15} \mathrm{~N} \quad\left({ }^{13} \mathrm{~F}={ }^{13} \mathrm{C} /\left[{ }^{12} \mathrm{C}+{ }^{13} \mathrm{C}\right]\right.$ and ${ }^{15} \mathrm{~F}={ }^{15} \mathrm{~N} /\left[{ }^{14} \mathrm{~N}+\right.$ $\left.{ }^{15} \mathrm{~N}\right]$ ) using a Costech 4010 Elemental Analyzer coupled to a Thermo Delta Plus XP IRMS at the University of Wyoming Stable Isotope Facility. The standard deviation of repeated analysis on laboratory standards $\left({ }^{15} \mathrm{~N}\right.$ enriched $\delta^{15} \mathrm{~N}$ standard and $\delta^{13} \mathrm{C}$ natural abundance standard) was 2 and $0.3 \%$, for $\delta^{15} \mathrm{~N}$ and $\delta^{13} \mathrm{C}$, respectively.

Recovery in moles of the ${ }^{13} \mathrm{C}$ and ${ }^{15} \mathrm{~N}$ label from component plant tissue (shoot, crown, or root) and soil and microbial biomass was calculated as

$$
{ }^{\mathrm{A}} X_{\mathrm{r}}=\left({ }^{\mathrm{A}} F_{1} \times[X] \times m\right)-\left({ }^{\mathrm{A}} F_{\mathrm{n}} \times[X] \times m\right),
$$

where ${ }^{\mathrm{A}} X_{\mathrm{r}}$ is the molar recovery of the label $\left({ }^{13} \mathrm{C}\right.$ or ${ }^{15} \mathrm{~N}$ ) in the component; ${ }^{\mathrm{A}} F_{1}$ and ${ }^{\mathrm{A}} F_{\mathrm{n}}$ are ${ }^{13} F$ and ${ }^{15} F$ of the component in labeled and non-labeled collars, respectively; $[X]$ is the moles of $\mathrm{C}$ or $\mathrm{N}$ per gram in the component; and $m$ is the mass in grams of the sample component. The moles of $\mathrm{N}$ and $\mathrm{C}$ per gram of shoot, crown, and root tissues used in the calculation were an average of that from the 5 replicate plots in each PHACE treatment (Table 1). Using an average of $\mathrm{C}$ and $\mathrm{N}$ per gram of plant tissue from the 5 replicates was necessary to reduce variation observed between experimental plots.

Plant label recovery in shoot, crown, and root tissues was calculated as

$$
{ }^{\mathrm{A}} X_{\mathrm{r} \text {,plant }}={ }^{\mathrm{A}} X_{\mathrm{r}, \text { shoot }}+{ }^{\mathrm{A}} X_{\mathrm{r}, \text { crown }}+{ }^{\mathrm{A}} X_{\mathrm{r}, \text { root }},
$$

where ${ }^{\mathrm{A}} X_{\mathrm{r}, \text { shoot }}{ }^{\mathrm{A}} X_{\mathrm{r} \text {, crown, }}$ and ${ }^{\mathrm{A}} X_{\mathrm{r}, \text { root }}$ are the molar ${ }^{13} \mathrm{C}$ or ${ }^{15} \mathrm{~N}$ recovery by shoot, crown, and root tissues, respectively.

The total amount of $\mathrm{C}$ or $\mathrm{N}$ in moles present in soils from experimental collars (untreated with chloroform) was averaged across the 5 replicate plots within each PHACE treatment for determination of label recovery due to high variability (Table 2 ).

Microbial $\mathrm{C}$ and $\mathrm{N}$ (mol per gram soil) in experimental collars were calculated according to Brookes and others (1985) as

$$
[X]_{\mathrm{mic}}=\left([X]_{\mathrm{soil}, \mathrm{F}}-[X]_{\mathrm{soil}, \mathrm{UF}}\right) / k,
$$

where $[X]_{\text {soil }, F}$ is the mol of $\mathrm{C}$ or $\mathrm{N}$ per gram of chloroform treated soil; $[X]_{\text {soil, UF }}$ is the moles of $\mathrm{C}$ or $\mathrm{N}$ per gram of soil untreated with chloroform; and $k$ is the extractable portion of microbial biomass $(0.45$ or 0.54 for $\mathrm{C}$ and $\mathrm{N}$, respectively; Brookes and others 1985; Beck and others 1997). The microbial $\mathrm{C}$ and $\mathrm{N}$ were averaged across the 5 replicate plots within each PHACE treatment for determination of label recovery due to high variability (Table 2 ).

We analyzed plant, soil, and microbial ${ }^{13} \mathrm{C}$ and ${ }^{15} \mathrm{~N}$ enrichments as well as $\mathrm{C}$ and $\mathrm{N}$ contents using a two-factor factorial split plot in space analysis of variance set in a completely randomized design (SAS Institute, version 9.3). Factors of interest were the PHACE treatments (whole plot), N preference (nested within PHACE treatments) (split plot), plus their interaction. When the null hypothesis for the main effect of either factor was rejected, the alternate was accepted, and when the interaction term was not significant (alpha $=0.05)$, post hoc analyses were conducted using Fisher's protected LSD on the main effect averages. No interactive effects of PHACE treatment and $\mathrm{N}$ preference were detected, so post hoc tests on interaction averages were not required. The main effect of PHACE treatment was tested against its error term, which was the pooled residuals of plots within level of PHACE treatment. The main effect of $\mathrm{N}$ preference plus the interaction term was also tested against the error mean square. Residuals were tested for normality using the Shapiro-Wilk statistic as well as assessing stem and leaf plots and normal probability plots. Homoscedasticity of variances was tested 


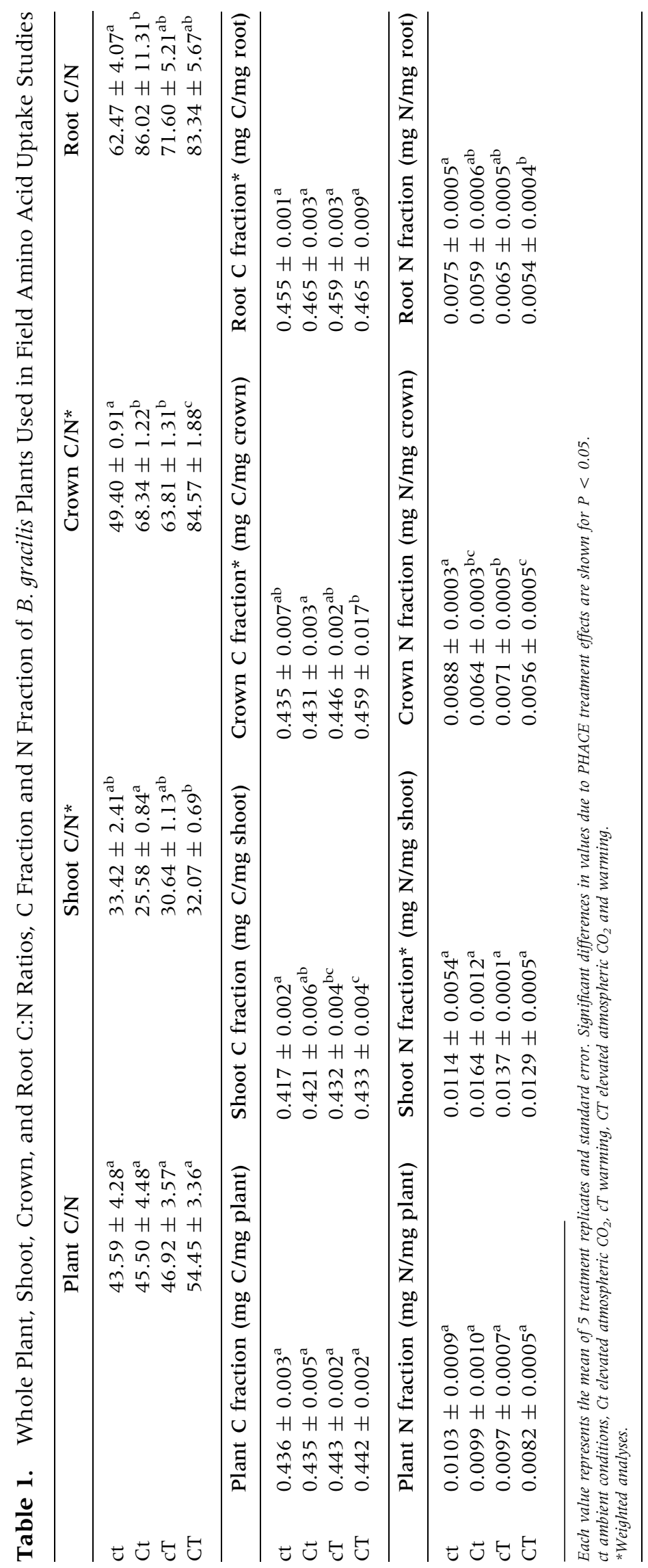


Table 2. Extracted Soil and Microbial C:N Ratios, Soil Soluble and Microbial C, and Soil Soluble and Microbial N from Field Amino Acid Uptake Studies

\begin{tabular}{llllcrr}
\hline & Soil C/N & Microbial C/N & $\begin{array}{l}\text { Soluble C } \\
(\mu \mathrm{mol} / \mathrm{g} \text { soil })\end{array}$ & $\begin{array}{c}\text { Microbial C } \\
(\mu \mathrm{mol} / \mathrm{g} \text { soil })\end{array}$ & $\begin{array}{c}\text { Soluble N } \\
(\mu \mathrm{mol} / \mathrm{g} \text { soil })\end{array}$ & $\begin{array}{r}\text { Microbial N } \\
(\mu \mathrm{mol} / \mathrm{g} \text { soil })\end{array}$ \\
\hline $\mathrm{Ct}$ & $5.83 \pm 0.8^{\mathrm{ab}}$ & $9.62 \pm 0.3^{\mathrm{a}}$ & $4.55 \pm 1.2^{\mathrm{a}}$ & $90.47 \pm 5.4^{\mathrm{a}}$ & $0.87 \pm 0.4^{\mathrm{a}}$ & $9.46 \pm 0.6^{\mathrm{a}}$ \\
$\mathrm{Ct}$ & $3.92 \pm 1.2^{\mathrm{a}}$ & $8.81 \pm 0.3^{\mathrm{a}}$ & $3.63 \pm 0.3^{\mathrm{a}}$ & $102.51 \pm 8.9^{\mathrm{a}}$ & $1.19 \pm 0.5^{\mathrm{a}}$ & $11.62 \pm 0.8^{\mathrm{a}}$ \\
$\mathrm{CT}$ & $4.71 \pm 0.6^{\mathrm{ab}}$ & $9.71 \pm 0.2^{\mathrm{a}}$ & $4.10 \pm 0.6^{\mathrm{a}}$ & $112.32 \pm 14.1^{\mathrm{a}}$ & $1.03 \pm 0.5^{\mathrm{a}}$ & $11.63 \pm 1.6^{\mathrm{a}}$ \\
CT & $7.31 \pm 1.8^{\mathrm{b}}$ & $9.17 \pm 0.5^{\mathrm{a}}$ & $4.46 \pm 0.6^{\mathrm{a}}$ & $105.98 \pm 12.9^{\mathrm{a}}$ & $0.65 \pm 0.3^{\mathrm{a}}$ & $11.50 \pm 1.1^{\mathrm{a}}$
\end{tabular}

Each value represents the mean of 5 treatment replicates and standard error. Significant differences in values due to PHACE treatment effects are shown for P < 0.05 . No weighted analyses were required.

ct ambient conditions, Ct elevated atmospheric $\mathrm{CO}_{2}, \mathrm{cT}$ warming, CT elevated atmospheric $\mathrm{CO}_{2}$ and warming.

Table 3. Mean Daily Soil Temperature at 3 and $10 \mathrm{~cm}$ Depths as well as Volumetric Water Content to $10 \mathrm{~cm}$ for Soils in April 2008 and June 2010

\begin{tabular}{|c|c|c|c|c|}
\hline & $\mathrm{ct}$ & $\mathrm{Ct}$ & $\mathrm{cT}$ & $\mathrm{CT}$ \\
\hline \multicolumn{5}{|l|}{ April 2008} \\
\hline Temperature at $3 \mathrm{~cm}\left({ }^{\circ} \mathrm{C}\right)$ & $7.0 \pm 0.1^{\mathrm{a}}$ & $6.9 \pm 0.1^{\mathrm{a}}$ & $9.2 \pm 0.1^{\mathrm{b}}$ & $9.0 \pm 0.1^{\mathrm{b}}$ \\
\hline Temperature at $10 \mathrm{~cm}\left({ }^{\circ} \mathrm{C}\right)$ & $6.6 \pm 0.1^{\mathrm{a}}$ & $6.3 \pm 0.1^{\mathrm{b}}$ & $8.1 \pm 0.1^{\mathrm{c}}$ & $8.2 \pm 0.1^{\mathrm{c}}$ \\
\hline Water content to $10 \mathrm{~cm}(\%)$ & $15.7 \pm 0.2^{\mathrm{ab}}$ & $16.8 \pm 0.2^{\mathrm{a}}$ & $13.5 \pm 0.1^{\mathrm{b}}$ & $16.2 \pm 0.2^{\mathrm{a}}$ \\
\hline \multicolumn{5}{|l|}{ June 2010} \\
\hline Temperature at $3 \mathrm{~cm}\left({ }^{\circ} \mathrm{C}\right)$ & $19.1 \pm 0.1^{\mathrm{a}}$ & $18.8 \pm 0.1^{\mathrm{a}}$ & $21.7 \pm 0.1^{\mathrm{b}}$ & $21.2 \pm 0.1^{\mathrm{b}}$ \\
\hline Temperature at $10 \mathrm{~cm}\left({ }^{\circ} \mathrm{C}\right)^{*}$ & $18.1 \pm 0.1^{\mathrm{a}}$ & $18.1 \pm 0.1^{\mathrm{a}}$ & $19.9 \pm 0.1^{\mathrm{b}}$ & $19.6 \pm 0.1^{\mathrm{b}}$ \\
\hline Water content to $10 \mathrm{~cm}(\%)$ & $15.5 \pm 0.3^{\mathrm{ad}}$ & $18.8 \pm 0.2^{\mathrm{b}}$ & $12.9 \pm 0.3^{c}$ & $16.3 \pm 0.3^{\mathrm{d}}$ \\
\hline
\end{tabular}

using Hartley's procedure and, when the variances were found to be heteroscedastic, the analyses were weighted by $\left(1 / s_{\mathrm{ij}}^{2}\right)^{0.5}$, where $\mathrm{s}_{\mathrm{ij}}^{2}$ were the variances of the ith PHACE treatment $\mathrm{x}$ jth $\mathrm{N}$ preference combination.

\section{Results}

\section{FAAs in PHACE plots}

Mean air temperature at the PHACE site during April 2008 when we evaluated FAA composition was $4.2^{\circ} \mathrm{C}$. Mean soil temperatures at 3 and $10 \mathrm{~cm}$ were highest, and soil volumetric water content to $10 \mathrm{~cm}$ was lowest in warmed plots. Soil volumetric water content was highest in elevated $\mathrm{CO}_{2}$ plots $(P<0.05$; Table 3).

Regardless of whether FAAs were extracted with deionized water or $\mathrm{K}_{2} \mathrm{SO}_{4}$ solution, phenylalanine and alanine were present in $0-5 \mathrm{~cm}$ soil extracts at higher abundance than other FAAs and comprised over $50 \%$ of the total amino-N (Figure 1A, C). Although alanine and phenylalanine remained the dominant forms of FAAs in $5-15 \mathrm{~cm}$ soil extracts collected with deionized water, this pattern did not hold for 5-15 cm soil extracts collected with $\mathrm{K}_{2} \mathrm{SO}_{4}$ (Figure 1D). Elevated $\mathrm{CO}_{2}$ and warming did not significantly affect FAA abundance or composition at either soil sampling depth.

\section{Plant FAA Uptake Capacity}

Biomass of 36-day-old B. gracilis and A. frigida plants used for FAA uptake experiments in hydroponic culture averaged $0.14 \pm 0.02$ and $0.13 \pm$ $0.02 \mathrm{~g}$ ( \pm : standard error), respectively. Root:shoot ratios of $B$. gracilis and A. frigida plants were $0.26 \pm$ 0.04 and $0.19 \pm 0.02$, and root biomass was $0.029 \pm 0.004$ and $0.019 \pm 0.003 \mathrm{~g}$, respectively. Within the first $30 \mathrm{~min}$ of alanine feeding, over $99 \%$ of all FAA was removed from the hydroponic culture solution by both plant species in both elevated $\mathrm{CO}_{2}$ and ambient growth chambers regardless of plant size and root:shoot ratios. No additional amino acids that might be present due to amino acid turnover or microbial contamination were detected at $30 \mathrm{~min}$. As $\mathrm{CO}_{2}$ treatments did not differ, all samples were combined for statistical analysis. Alanine uptake per gram root dry mass 


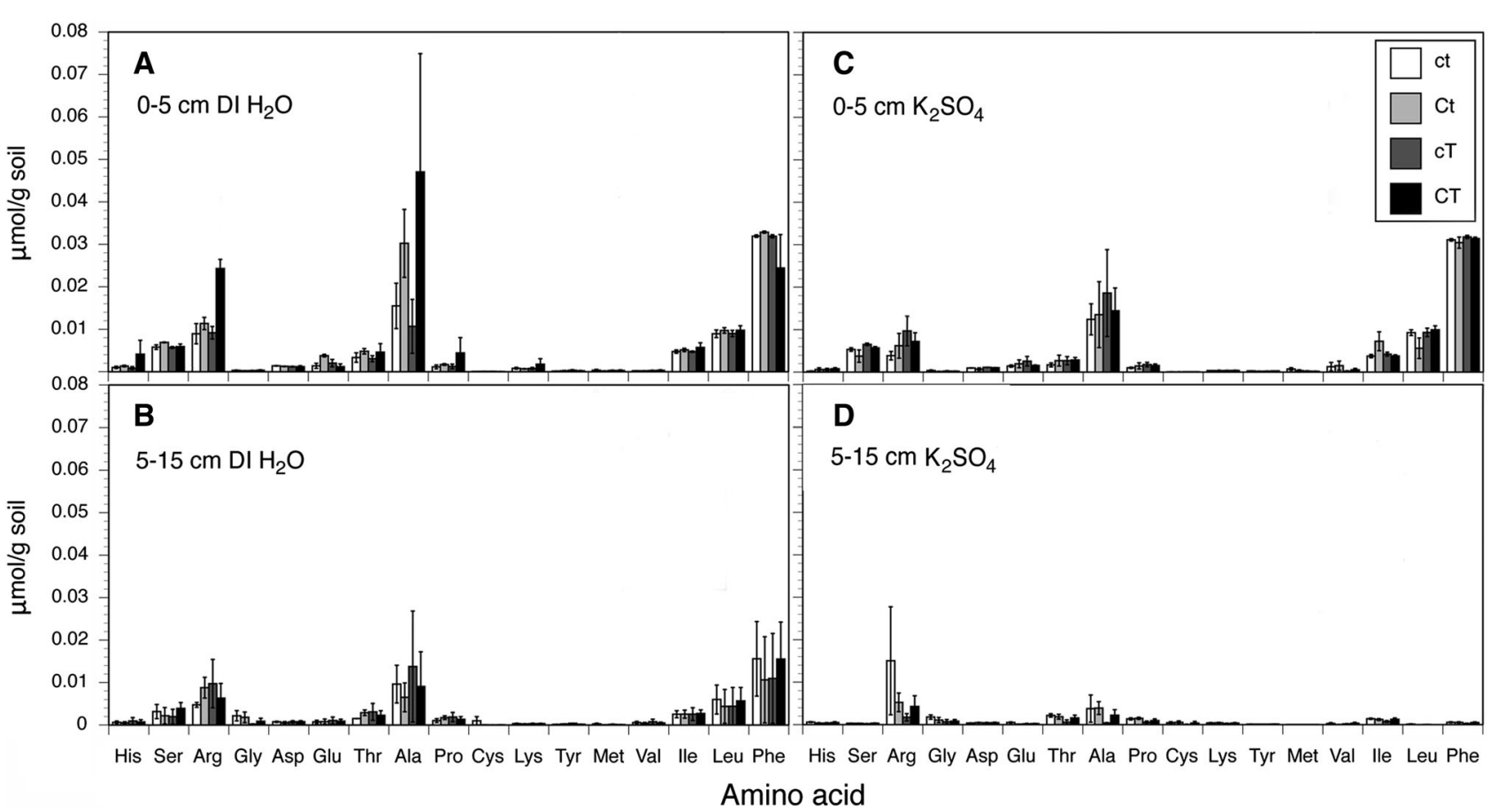

Figure 1. Abundance of FAAs per gram of soil $\left(\mu \mathrm{mol} \mathrm{g}{ }^{-1}\right)$ in the experimental site in April 2008 from extracts collected

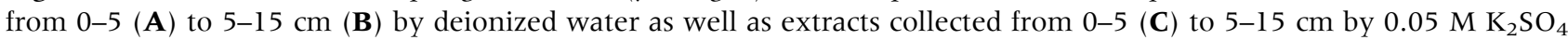
(D). Both solutions are commonly used to extract soil $\mathrm{N}$ compounds. Soil extracts collected in plots with ambient conditions, elevated atmospheric $\mathrm{CO}_{2}$, warming and elevated atmospheric $\mathrm{CO}_{2}$, and warming were labeled as $\mathrm{ct}$, $\mathrm{Ct}$, $\mathrm{cT}$, and CT, respectively. Each bar represents an average of 5 treatment replicates. Error bars indicate SE.

Table 4. Alanine, Phenylalanine, or Nitrate Uptake after 30 min by Hydroponic Cultured Plants Expressed on a Root Dry Mass Basis

\begin{tabular}{lllc}
\hline Species & Alanine $\left(\mu \mathrm{mol} \mathrm{g}{ }^{-1}\right)$ & Phenylalanine $\left(\mu \mathrm{mol} \mathrm{g}{ }^{-1}\right)$ & $\mathrm{NO}_{3}(\mu \mathrm{mol} \mathrm{g})$ \\
\hline B. gracilis & $2329 \pm 529$ & $2011 \pm 952$ & $18 \pm 93$ \\
A. frigida & $2324 \pm 566$ & $3164 \pm 675$ & $444 \pm 723$
\end{tabular}

Values represent means of 4 replicates and standard error.

after 30 min feeding averaged 2329 and $2323 \mu \mathrm{mol}$ for $B$. gracilis and A. frigida, respectively. Similar results were observed for plants fed with phenylalanine (Table 4). Conversely, plants that were transferred to nitrate took up little to none of this inorganic $\mathrm{N}$ form (Table 4). The majority of ${ }^{14} \mathrm{C}$ labeled alanine fed to $B$. gracilis and $A$. frigida plants remained in root and crown tissues after $3 \mathrm{~h}$ of feeding, although radiolabel was visible in shoot tissue as well (Figure 2).

\section{FAA Preference and PHACE Field Experiment}

Mean daily air temperature was $16.3^{\circ} \mathrm{C}$ in June 2010 during the labeling study. Mean soil temperatures at 3 and $10 \mathrm{~cm}$ were significantly higher in warmed treatment compared to ambient treatment plots. Soil volumetric water content to $10 \mathrm{~cm}$ was affected by elevated $\mathrm{CO}_{2}$ and warming $(P<0.05$; Table 3$)$ and was highest in elevated $\mathrm{CO}_{2}$ plots. The average soil moisture content in experimental collars after the feeding ranged from 23.0 to $24.7 \%$ among PHACE treatments. After the $3 \mathrm{~h}$ feeding, the majority of ${ }^{15} \mathrm{~N}$ from each labeled $\mathrm{N}$ source and ${ }^{13} \mathrm{C}$ from labeled alanine was detected in microbial biomass (Figure 3). Up to $70 \%$ of ${ }^{15} \mathrm{~N}$ was recovered in microbial biomass, but $\mathrm{N}$ form, $\mathrm{CO}_{2}$, and warming did not significantly affect recovery $(P>0.05)$. Less than $5 \%$ of ${ }^{15} \mathrm{~N}$ was recovered in whole $B$. gracilis plant tissue and 4$20 \%$ of ${ }^{15} \mathrm{~N}$ was recovered in soil. ${ }^{15} \mathrm{~N}$ in plant tissues significantly increased $(P=0.048)$ in elevated $\mathrm{CO}_{2}$ and warming treatments compared to ambient 

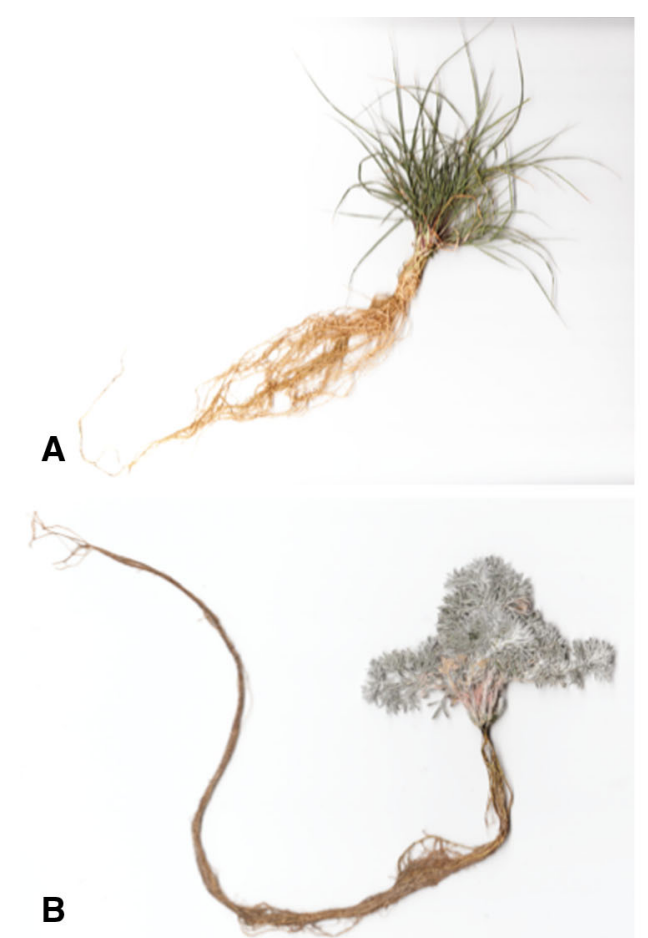

c
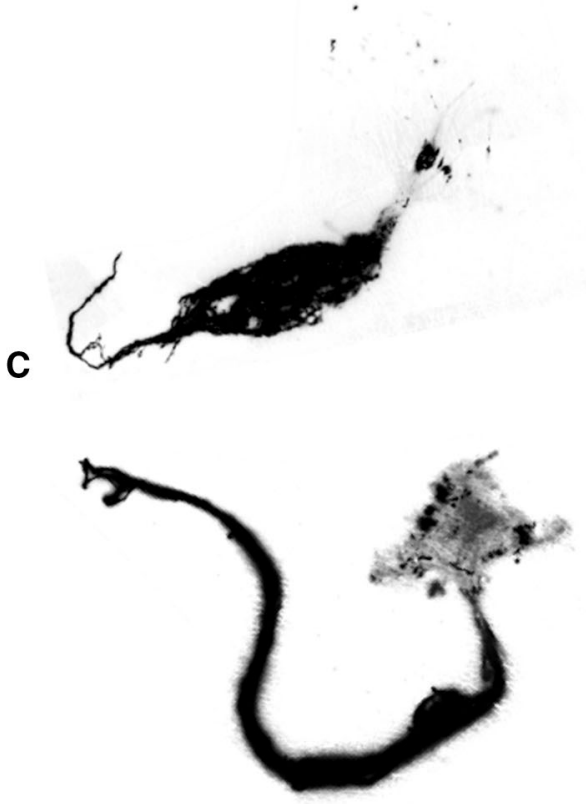

Figure 2. Allocation of L- $\left[2-{ }^{14} \mathrm{C}\right]$ alanine in $B$. gracilis and $A$. frigida plants. Dried, pressed $B$. gracilis and $A$. frigida plants (A, B, respectively) and their autoradiographs (C, D). Roots were fed alanine $-{ }^{14} \mathrm{C}$ for $3 \mathrm{~h}$ and then washed with $0.5 \mathrm{M}$ $\mathrm{CaCl}_{2}$, dried pressed and exposed to X-ray films. Films were developed after 8 months of exposure. and elevated $\mathrm{CO}_{2}$ plus warming treatments regardless of the labeled ${ }^{15} \mathrm{~N}$ form. Recovery of ${ }^{15} \mathrm{~N}$ in soil was significantly lower $(P=0.025)$ in the elevated $\mathrm{CO}_{2}$ plus warming treatment compared to those in ambient or warmed treatments, regardless of the labeled ${ }^{15} \mathrm{~N}$ form. Forty-four to fifty-two percent of alanine $-{ }^{13} \mathrm{C}$ was recovered in microbial biomass, $0-1 \%$ was recovered in plant biomass, and none was recovered in soils (Figure 3). Elevated $\mathrm{CO}_{2}$ and warming did not significantly affect ${ }^{13} \mathrm{C}$ recovery $(P>0.05)$. The ${ }^{13} \mathrm{C} /{ }^{15} \mathrm{~N}$ ratio of microbial biomass that was fed with labeled alanine did not match that of the alanine source ${ }^{13} \mathrm{C} /{ }^{15} \mathrm{~N}$ ratio of 1 , but the average ratio of 0.83 suggests most of the amino acid was acquired through direct uptake. PHACE treatments had variable effects on $B$. gracilis shoot, crown, and root $\mathrm{C}$ and $\mathrm{N}$ status (Table 1). PHACE treatments also had variable effects on soil $\mathrm{C} / \mathrm{N}$ status after the $\mathrm{N}$ feeding period but did not affect soluble $\mathrm{K}_{2} \mathrm{SO}_{4}$ extracted soil $\mathrm{C}$ and $\mathrm{N}$ and microbial $\mathrm{C}$ and $\mathrm{N}$ status nor indicate an increase of microbial $\mathrm{N}$ limitation with elevated $\mathrm{CO}_{2}$ or decrease with warming (Table 2).

\section{Discussion}

Contrary to our prediction that grassland plants would increase uptake of FAAs under elevated $\mathrm{CO}_{2}$, direct uptake of fed alanine was not observed in the dominant C4 grass B. gracilis in our field experiment across any of the global change treatments. This was evident from the absence of any ${ }^{13} \mathrm{C}$ recovery in plant tissues after exposure to ${ }^{13} \mathrm{C}$ labeled alanine. The lack of plant FAA uptake in the field contrasts with observations from our hydroponic culture experiment that showed a capacity for rapid uptake of FAAs by B. gracilis and the common sub-shrub $A$. frigida. Furthermore, inorganic $\mathrm{N}$ uptake was minimal in B. gracilis after a $3 \mathrm{~h}$ feeding in the field. Soil microorganisms acquired the majority of $\mathrm{N}$ from alanine, ammonium, and nitrate and $\mathrm{C}$ from the alanine introduced within the short-term feeding. In addition, FAA concentrations were unaffected by elevated atmospheric $\mathrm{CO}_{2}$ and warming. Although roots of prairie plants from our field site are capable of taking up FAA forms present in soil, FAAs appear to be an unimportant direct $\mathrm{N}$ source for these plants in the field.

\section{FAAs in PHACE Soils}

Among FAAs detected within our semiarid grassland, alanine and phenylalanine were present in the highest concentrations, and FAA abundance was not affected by elevated atmospheric $\mathrm{CO}_{2}$ or warming. However, in a concurrent study at the PHACE site, dissolved organic $\mathrm{N}$ pools were affected by elevated $\mathrm{CO}_{2}$ and warming, particularly in wet years such as 2009 which accumulated $453 \mathrm{~mm}$ of precipitation (Carrillo and others 2012). Thus, we may have observed treatment effects had we sampled FAAs in a wet year rather than our sampled 

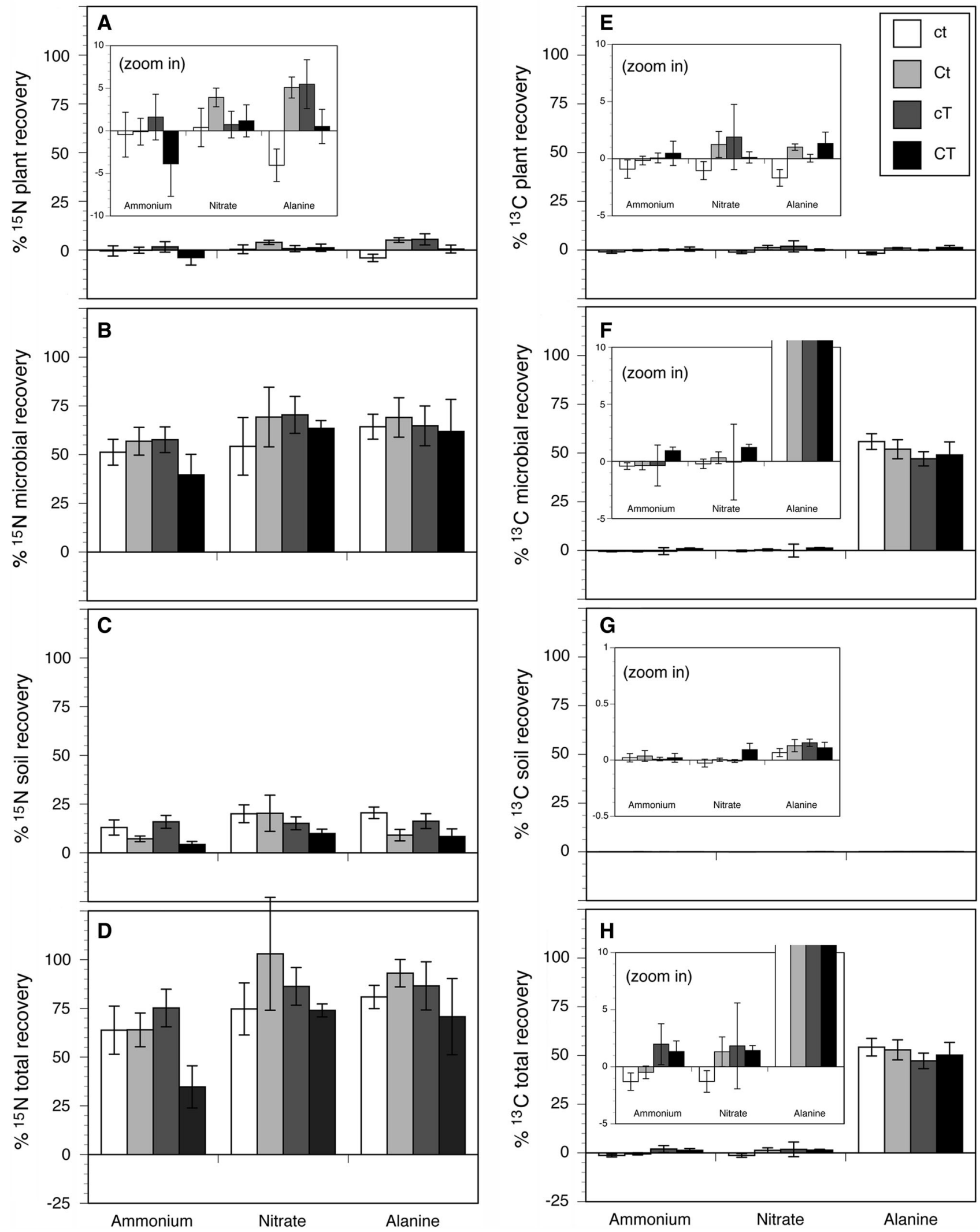
4 Figure 3. Percent ${ }^{15} \mathrm{~N}$ and ${ }^{13} \mathrm{C}$ recovery detected in plant $(\mathbf{A}, \mathbf{E})$, microbial $(\mathbf{B}, \mathbf{F})$, and soil samples $(\mathbf{C}, \mathbf{G})$ as well as total ${ }^{15} \mathrm{~N}$ and ${ }^{13} \mathrm{C}$ recovery $(\mathbf{D}, \mathbf{H})$ after $3 \mathrm{~h}$ feeding of ${ }^{15} \mathrm{~N}$-labeled ammonium, ${ }^{15} \mathrm{~N}$-labeled nitrate, or ${ }^{15} \mathrm{~N} /{ }^{13} \mathrm{C}$ labeled alanine. A, E-H contain zoom in expansions for better bar resolution at low ${ }^{15} \mathrm{~N}$ and ${ }^{13} \mathrm{C}$ recovery. Samples collected from plots with ambient conditions, elevated atmospheric $\mathrm{CO}_{2}$, warming and elevated atmospheric $\mathrm{CO}_{2}$, and warming were labeled as ct, Ct, cT and $\mathrm{CT}$, respectively. Each bar represents an average of 5 treatment replicates. Error bars indicate SE.

year that only accumulated $327 \mathrm{~mm}$ of precipitation. The dominance of alanine and phenylalanine within our soil extracts also contrasts with other grassland studies where glycine, glutamate, aspartate, and serine were detected at highest concentrations and were, along with other FAAs, shown to be affected by temperature (Amelung and others 2006). Differences between these studies may have resulted from differences in how FAAs were extracted (Chen and Williams 2013), time of sampling (Raab and others 1999; Werdin-Pfisterer and others 2009), or may simply be characteristic of our system. Regardless of the method and timing of soil sampling, FAAs collected in our experiment should be considered a potential plant $\mathrm{N}$ source within our semiarid grassland.

\section{Plant FAA Uptake Capacity}

Root uptake of alanine and phenylalanine by $B$. gracilis and $A$. frigida was rapid in hydroponic culture. We assume that depletion of FAAs from hydroponic solution was due solely to plant uptake because there was no evidence of microbial contamination (Chen and Williams 2013). Our radiographs of plants fed with L- $\left[2-{ }^{14} \mathrm{C}\right]$ alanine also demonstrate that alanine-carbon was present in root and shoot tissues after $3 \mathrm{~h}$, further demonstrating plant FAA assimilation. Uptake of alanine and phenylalanine by grasses is well documented and can vary between species (Falkengren-Grerup and others 2000; Weigelt and others 2005; Harrison and others 2007, 2008). Yet, alanine and phenylalanine uptake rates did not differ between B. gracilis and A. frigida in our study. We hypothesize that FAA uptake capacity was maximized due to the lack of microbial competitors for $\mathrm{N}$ and optimal growth conditions under hydroponic culture. Uptake of alanine and phenylalanine in hydroponic culture confirmed that $B$. gracilis and $A$. frigida have the potential to acquire these forms of FAAs in the absence of microbial competition. In contrast, $B$. gracilis and $A$. frigida uptake of nitrate was low. Initial seedling growth in our $\mathrm{NH}_{4} \mathrm{NO}_{3}$ hydroponic solution may have acclimated plant inorganic
$\mathrm{N}$ transporters and resulted in a steady, slow rate of nitrate uptake. Thus, transporters involved in root uptake of FAAs likely experienced rapid up-regulation of expression and activity after induction on FAAs that were never present before whereas nitrate transporters did not (Hole and others 1990; Chen 2006).

\section{FAA Preference and PHACE Field Experiment}

Rapid microbial sequestration and negligible plant uptake of ${ }^{15} \mathrm{~N}$ and ${ }^{13} \mathrm{C}$ tracers indicate strong microbial competition for soil $\mathrm{N}$ relative to plants in our semiarid grassland site. Strong microbial competition for inorganic and organic $\mathrm{N}$ was also observed in temperate grassland and heath ecosystems (Jackson and others 1989; Bardgett and others 2003; Andresen and others 2009). Negligible plant $\mathrm{N}$ uptake was likely the result of higher proliferation of microbial biomass and access to $\mathrm{N}$ in soils (Bardgett and others 2003). We hypothesize that fungi are responsible for the majority of shortterm $\mathrm{N}$ immobilization due to the larger proportion of fungi to bacteria in grasslands and fungal capacity to sequester N (Bardgett and others 1993; Grayston and others 2001). Low plant uptake of N sources was unlikely due to soil moisture and diffusion limitation (Gebauer and Ehlringer 2000) because cores were given additional water at the time of $\mathrm{N}$ feeding and had high soil moisture content at the end of the experiment. Because no alanine ${ }^{13} \mathrm{C}$ label was found in soils after the feeding period, we conclude that longer feeding periods would not result in direct plant uptake of the FAA.

The concept that soil microorganisms are likely strong short-term competitors for soil $\mathrm{N}$ and that plants are long-term competitors (Hodge and others 2000; Bardgett and others 2003) is supported by our observation of high ${ }^{15} \mathrm{~N}$ recovery in microbial biomass and low recovery in plant biomass after a $3 \mathrm{~h}$ feeding. These results contrast with observations from other studies conducted in grasslands (Harrison and others 2007, 2008). The duration of $\mathrm{N}$ feeding among studies may explain these differences, as $\mathrm{N}$ feedings in published studies range from $3 \mathrm{~h}$ to 33 days, with the majority of feeding periods lasting 24-50 h (Schimel and Chapin 1996; Näsholm and others 2001; Bardgett and others 2003; Harrison and others 2007; Hofmockel and others 2007; Andresen and others 2008, 2009). Among these studies, those that tested multiple duration feeding periods suggest that longer feeding times detect greater plant $\mathrm{N}$ uptake (Schimel and Chapin 1996; Bardgett and others 2003; Harrison and 
others 2007). Apparent uptake of FAAs after extended feeding periods may be due to uptake of mineralized N and C (Sauheitl and others 2009) and rapid turnover of FAAs (Jones 1999) rather than direct uptake of FAA N. After 24-50 h of N feeding, $\mathrm{N}$ is likely acquired by plants through $\mathrm{N}$ release by mycorrhizae as well as by soil $\mathrm{N}$ mineralization and microbial turnover (Jones and Kielland 2002; Schimel and Bennett 2004; Govindarajulu and others 2005). High microbial ${ }^{15} \mathrm{~N}$ and ${ }^{13} \mathrm{C}$ recovery may also be due to the lag time between the feeding experiment and soil processing, but we do not suspect this is the case. Soils were quickly harvested after the feeding experiment and placed on ice and then refrigerated until soil processing and low temperatures should have inhibited additional microbial N uptake (Reay and others 1999; Nedwell 2006). Additional studies have also demonstrated rapid microbial sequestration of $\mathrm{N}$ sources within $3 \mathrm{~h}$ and support our results (Hofmockel and others 2007). Unrecovered ${ }^{15} \mathrm{~N}$ and ${ }^{13} \mathrm{C}$ from alanine, ammonium, and nitrate labels were likely attributed to loss from respiration and volatilization to the atmosphere (Koops and others 1997; Jin and Evans 2010). Additionally, ${ }^{15} \mathrm{~N}$ and ${ }^{13} \mathrm{C}$ labels may have been consumed by excised roots of other plants present in soil collars and lost due to exclusive collection of intact $B$. gracilis plant material and soil (Falkengren-Grerup and others 2000).

Elevated $\mathrm{CO}_{2}$ and warming increased plant ${ }^{15} \mathrm{~N}$ uptake, but plants did not shift $\mathrm{N}$ preference. Additionally, elevated $\mathrm{CO}_{2}$ combined with warming did not increase plant $\mathrm{N}$ uptake compared to ambient conditions. It is possible that 2 years of atmospheric $\mathrm{CO}_{2}$ enrichment may have been too short to exacerbate $\mathrm{N}$ limitation and increase plant demand for FAAs. This is supported by the lack of PHACE treatment effects on whole plant $\mathrm{C} / \mathrm{N}$ ratios of $B$. gracilis. If $\mathrm{N}$ becomes more limiting under elevated $\mathrm{CO}_{2}$ over the period of decades or longer, plants may increasingly compete with microbes for FAAs.

Although alanine and phenylalanine are present in grassland, soils and plants can acquire these FAAs, plants took up little to no FAAs or inorganic $\mathrm{N}$ over the short-term in our study due to rapid and strong microbial competition. A combination of hydroponic culture and short-term field labeling studies was necessary to reach this conclusion. $\mathrm{N}$ demands are likely met in this grassland through low rates of $\mathrm{N}$ uptake and long-term storage of released microbial N. Additionally, plants probably do not acquire FAAs directly and likely require mycorrhizal transfer and microbial release of $\mathrm{N}$ prior to plant use.

\section{ACKNOWLEDGMENTS}

Special thanks to David Legg, David Perry, Dan Lecain, Chandelle MacDonald, Amanda Brennan, Dana Blumenthal, Justin Jones, Erik Hobbie, and Jane Zelikova for manuscript, laboratory, and field assistance. This material is based upon work supported by the US Department of Agriculture Agricultural Research Service Climate Change, Soils $\&$ Emissions Program, USDA-CSREES Soil Processes Program (\#2008-35107-18655), US Department of Energy Office of Science (BER), through the Terrestrial Ecosystem Science program (\#DE-SC0006973) and the Western Regional Center of the National Institute for Climatic Change Research, and by the National Science Foundation (DEB\#1021559). Any opinions, findings, and conclusions or recommendations expressed in this material are those of the author(s) and do not necessarily reflect the views of the National Science Foundation.

\section{REFERENCES}

Amelung W, Zhang X, Flach KW. 2006. Amino acids in grassland soils: climatic effects on concentrations and chirality. Geoderma 130:207-17.

Andresen LC, Jonasson S, Strom L, Michelsen A. 2008. Uptake of pulse injected nitrogen by soil microbes and mycorrhizal and non-mycorrhizal plants in a species diverse subarctic heath ecosystem. Plant Soil 313:283-95.

Andresen LC, Michelsen A, Jonasson S, Beier C, Ambus P. 2009. Glycine uptake in heath plants and soil microbes responds to elevated temperature, $\mathrm{CO}_{2}$ and drought. Acta Oecologia 35:786-96.

Bardgett RD, Whittaker JB, Frankland JC. 1993. The effect of collembolan grazing on fungal activity in differently managed upland pastures-a microcosm study. Biol Fertil Soil 16:255-62.

Bardgett RD, Streeter TC, Bol R. 2003. Soil microbes compete effectively with plants for organic-nitrogen inputs to temperate grasslands. Ecology 84:1277-87.

Beck T, Joergensen RG, Kandeler E, Makeschin F, Nuss E, Oberholzer HR, Scheu S. 1997. An inter-laboratory comparison of ten different ways of measuring soil microbial biomass C. Soil Biol Biochem 29:1023-32.

Blumenthal D. 2009. Carbon addition interacts with water availability to reduce invasive forb establishment in a semiarid grassland. Biol Invasion 11:1281-90.

Brookes PC, Landman A, Prudent G, Jenkinson DS. 1985. Chloroform fumigation and the release of soil nitrogen: a rapid direct extraction method to measure microbial biomass nitrogen in soil. Soil Biol Biochem 17:837-42.

Brzostek ER, Blair JM, Dukes JS, Frey SD et al. 2012. The effect of experimental warming and precipitation change on proteolytic enzyme activity: positive feedbacks to nitrogen availability are not universal. Global Change Biol 18:2617-25.

Carrillo Y, Dijkstra FA, Pendall E, Morgan JA, Blumenthal DM. 2012. Controls over soil nitrogen pools in a semiarid grassland under elevated $\mathrm{CO}_{2-}$ and warming. Ecosystems 15:761-74. 
Chapin FSIII, Moilanen L, Kielland K. 1993. Preferential use of organic nitrogen for growth by a non-mycorrhizal sedge. Nature 361:150-3.

Chen J. 2006. Analysis of the role of AAPl in amino acid transport in Arabidopsis thaliana. Masters thesis. Pullman, USA: Washington State University.

Chen J, Williams DG. 2013. A novel in situ water perfusion and extraction method for soil amino acid quantification. Soil Biol Biochem 59:86-8.

Dijkstra FA, Blumenthal D, Morgan JA, Pendall E, Carrillo Y, Follett RF. 2010. Contrasting effects of elevated $\mathrm{CO}_{2}$ and warming on nitrogen cycling in a semiarid grassland. New Phytol 187:426-37.

Falkengren-Grerup U, Mansson KF, Olsson MO. 2000. Uptake capacity of amino acids by ten grasses and forbs in relation to soil acidity and nitrogen availability. Environ Exp Bot 44:207-19.

Finzi AC, Berthrong ST. 2005. The uptake of amino acids by microbes and trees in three cold-temperate forests. Ecology 86:3345-53

Gallet-Budynek A, Brzostek E, Rodgers VL, Talbot JM, Hyzy S, Finz AC. 2009. Intact amino acid uptake by northern hardwood and conifer trees. Oecologia 160:129-38.

Gebauer RLE, Ehlringer JR. 2000. Water and nitrogen uptake patterns following moisture pulses in a cold desert community. Ecology 81:1415-24.

Govindarajulu M, Pfeffer PE, Jin H et al. 2005. Nitrogen transfer in the arbuscular mycorrhizal symbiosis. Nature 435:819-23.

Grayston S, Griffiths G, Mawdsley JL, Cambell C, Bardgett RD. 2001. Accounting for variability in soil microbial communities of temperate upland grasslands. Soil Biol Biochem 33:533-51.

Harrison KA, Bol R, Bardgett RD. 2007. Preferences for different nitrogen forms by coexisting plant species and soil microbes. Ecology 4:989-99.

Harrison KA, Bol R, Bardgett RD. 2008. Do plant species with different growth strategies vary in their ability to compete with soil microbes for chemical forms of nitrogen? Soil Biol Biochem 40:228-37.

Hodge A, Robinson D, Fitter A. 2000. Are microorganisms more effective than plants at competing for nitrogen? Trends Plant Sci 5:304-8.

Hofmockel KS, Schlesinger WH, Jackson RB. 2007. Effects of elevated atmospheric carbon dioxide on amino acid and $\mathrm{NH}_{4}{ }^{+}$$\mathrm{N}$ cycling in a temperate pine ecosystem. Global Change Biol 13:1950-9.

Hole DJ, Emran AM, Fares Y, Drew MC. 1990. Induction of nitrate transport in maize roots, and kinetics of influx, measured with nitrogen-13. Plant Physiol 93:642-7.

Inselsbacher E. 2014. Recovery of individual soil nitrogen forms after sieving and extraction. Soil Biol Biochem 71:76-86.

Jackson LE, Schimel JP, Firestone MK. 1989. Short-term partitioning of ammonium and nitrate between plants and microbes in an annual grassland. Soil Biol Biochem 21:409-15.

Jin VL, Evans RD. 2010. Elevated $\mathrm{CO}_{2}$ increases plant uptake of organic and inorganic $\mathrm{N}$ in the desert shrub Larrea tridentata. Oecologia 163:257-66.

Jones DL. 1999. Amino acid biodegradation and its potential effects on organic nitrogen capture by plants. Soil Biol Biochem 31:613-22.

Jones DL, Kielland K. 2002. Soil amino acid turnover dominates the nitrogen flux in permafrost-dominated taiga forest soils. Soil Biol Biochem 24:209-19.
Kaye J, Barrett J, Burke I. 2002. Stable nitrogen and carbon pools in grassland soils of variable texture and carbon content. Ecosystems 5:461-71.

Kimball BA, Conley MM, Wang S, Lin X, Luo C, Morgan J, Smith D. 2008. Infrared heater arrays for warming ecosystem field plots. Global Change Biol 14:309-20.

King JY, Mosier AR, Morgan JA, LeCain DR, Milchunas DG, Parton WJ. 2004. Plant nitrogen dynamics in shortgrass steppe under elevated atmospheric carbon dioxide. Ecosystems $7: 147-60$

Koops JG, van Beusichem ML, Oenema O. 1997. Nitrogen loss from grassland on peat soils through nitrous oxide production. Plant Soil 188:119-30.

Larsen KS, Jonasson S, Michelsen A. 2002. Repeated freezethaw cycles and their effects on biological processes in two arctic ecosystem types. Appl Soil Ecol 21:187-95.

Lee YH, Foster J, Chen J, Voll LM, Weber APM, Tegeder M. 2007. AAPl transports uncharged amino acids into roots of Arabidopsis. Plant J 50:305-19.

Lipson DA, Monson RK. 1998. Plant-microbe competition for soil amino acids in the alpine tundra: effects of freeze-thaw and dry-rewet events. Oecologia 113:406-14.

Lipson DA, Schadt CW, Schmidt SK, Monson RK. 1999. Ectomycorrhizal transfer of amino acid nitrogen to the alpine sedge Kobresia myosuroides. New Phytol 142:163-7.

Luo Y, Su B, Currie WS, Dukes JS, Finzi A et al. 2004. Progressive nitrogen limitation of ecosystem responses to rising atmospheric carbon dioxide. Bioscience 54:731-9.

Luo Y, Field CB, Jacskon RB. 2006. Does nitrogen constrain carbon cycling, or does carbon input stimulate nitrogen cycling? Ecology 87:3-4.

Miglietta F, Hoosbeek MR, Foot J, Gigon F, Hassinen A, Heijmans M, Peressotti A, Saarienen T, van Breemen N, Wallen B. 2001. Spatial and temporal performance of the miniface (free air $\mathrm{CO}_{2}$ enrichment) system on bog ecosystems in northern and central Europe. Environ Monit Assess 66:107-27.

Näsholm T, Huss-Danell K, Högberg P. 2001. Uptake of glycine by field grown wheat. New Phytol 150:59-63.

Nedwell DB. 2006. Effect of low temperature on microbial growth: lowered affinity for substrates limits growth at low temperature. Microbiol Ecol 30:101-11.

Newton PCD, Lieffering M, Bowatte WMSD, Brock SC, Hunt CL, Theobald PW, Ross DJ. 2010. The rate of progression and stability of progressive nitrogen limitation at elevated atmospheric $\mathrm{CO}_{2}$ in a grazed grassland over 11 years of Free Air $\mathrm{CO}_{2}$ enrichment. Plant Soil 336:433-41.

Pendall E, Bridgham S, Hanson PJ, Hungate B et al. 2004. Below-ground process responses to elevated $\mathrm{CO}_{2}$ and temperature: a discussion of observations, measurement methods and models. New Phytol 162:311-22.

Raab TK, Lipson DA, Monson RK. 1996. Non-mycorrhizal uptake of amino acids by roots of the alpine sedge Kobresia myosuroides: implications for the alpine nitrogen cycle. Oecologia 108:488-94

Raab TK, Lipson DA, Monson RK. 1999. Soil amino acid utilization among species of the Cyperaceae: plant and soil processes. Ecology 80:2408-19.

Reay DS, Nedwell DB, Priddle J, Cynan Ellis-Evans J. 1999. Temperature dependence of inorganic nitrogen uptake: reduced affinity for nitrate at suboptimal temperatures in both algae and bacteria. Appl Environ Microbiol 65(2577):2584. 
Saugier B, Roy J, Mooney HA. 2001. Estimations of global terrestrial productivity: converging toward a single number? In: Roy J, Saugier B, Mooney HA, Eds. Terrestrial global productivity. San Diego: Academic Press.

Sauheitl L, Glaser B, Weigelt A. 2009. Advantages of compoundspecific stable isotope measurements over bulk measurements in studies on plant uptake of intact amino acids. Rapid Commun Mass Spectrom 23:3333-42.

Schimel JP, Chapin FSIII. 1996. Tundra plant uptake of amino acid and $\mathrm{NH}_{4}{ }^{+}$nitrogen in situ: plants compete well for amino acid N. Ecology 77:2142-7.

Schimel JP, Bennett J. 2004. Nitrogen mineralization: challenges of a changing paradigm. Ecology 85:591-602.

Vitousek PM, Howarth RW. 1991. Nitrogen limitation on land and in the sea-how can it occur? Biogeochemistry 13:87115.

Warren CR. 2013. High diversity of soil organic N observed in soil water. Soil Biol Biochem 57:444-50.
Weigelt A, Bol R, Bardgett RD. 2005. Preferential uptake of soil nitrogen forms by grassland plant species. Oecologia 142:62735.

Werdin-Pfisterer NR, Kielland K, Boone RD. 2009. Soil amino acid composition across a boreal forest successional sequence. Soil Biol Biochem 41:1210-20.

West NE. 1991. Nutrient cycling in soils of semi arid and arid regions. In: Skujins J, Ed. Semi arid lands and deserts: soil resource and reclamation. New York: Marcel Dekker Inc. p 295-332.

Williams LE, Miller AJ. 2001. Transporters responsible for the uptake and partitioning of nitrogenous solutes. Annu Rev Plant Physiol Plant Mol Biol 52:659-88.

Zak DR, Holmes WE, Finzi AC, Norby RJ, Schlesinger WH. 2003. Soil nitrogen cycling under elevated $\mathrm{CO}_{2}$ : a synthesis of forest FACE experiments. Ecol Appl 13:1508-14. 